\title{
A comparative study of three different PCR assays for detection of Mycoplasma genitalium in urogenital specimens from men and women
}

\author{
Andreas Edberg, ${ }^{1}$ Margaretha Jurstrand, ${ }^{2}$ Eva Johansson, ${ }^{3}$ \\ Elisabeth Wikander, ${ }^{1}$ Anna Höög, ${ }^{1}$ Thomas Ahlqvist, ${ }^{1}$ Lars Falk, ${ }^{4,5}$ \\ Jørgen Skov Jensen ${ }^{6}$ and Hans Fredlund ${ }^{2}$ \\ ${ }^{1}$ Department of Clinical Microbiology, Central Hospital, SE-651 85 Karlstad, Sweden \\ ${ }^{2}$ Department of Clinical Microbiology, University Hospital, SE-701 85 Örebro, Sweden \\ ${ }^{3}$ Department of Infectious Diseases, Central Hospital, SE-651 85 Karlstad, Sweden \\ ${ }^{4}$ Department of Dermatology and Venereology, Linköping University Hospital, County of \\ Östergötland, SE-581 85 Linköping, Sweden \\ ${ }^{5}$ R\&D Department of Local Health Care, County of Östergötland, SE-581 85 Linköping, Sweden \\ ${ }^{6}$ Mycoplasma Laboratory, Statens Serum Institute, DK-2300 Copenhagen S, Denmark
}

Correspondence

Andreas Edberg

andreas.edberg@liv.se

Received 5 July 2007

Accepted 22 November 2007

\begin{abstract}
The aim of this study was to compare conventional 16S rRNA gene PCR, real-time 16S rRNA gene PCR and real-time Mycoplasma genitalium adhesin protein ( $\mathrm{MgPa}$ ) gene PCR as detection methods for M. genitalium infection. The study also determined the prevalence of $M$. genitalium in male and female patients attending a sexually transmitted infections clinic in a rural area in the west of Sweden. First void urine (FVU) and/or urethral swabs were collected from 381 men, and FVU and/or cervical swabs and/or urethral swabs were collected from 298 women. A total of 213 specimens were used in the PCR comparative study: 98 consecutively sampled specimens from patients enrolled in the prevalence study, 36 consecutively sampled specimens from patients with symptoms of urethritis and 79 specimens from patients positive for M. genitalium by real-time $\mathrm{MgPa}$ gene PCR in the prevalence study. A true-positive M. genitalium DNA specimen was defined as either a specimen positive in any two PCR assays or a specimen whose PCR product was verified by DNA sequencing. The prevalence of $M$. genitalium infection in men and women was $27 / 381(7.1 \%)$ and $23 / 298$ (7.7\%), respectively. In the PCR comparative study, $M$. genitalium DNA was detected in $61 / 76$ (80.3\%) of true-positive specimens by conventional 16S rRNA gene PCR, in 52/76 (68.4\%) by real-time 16S rRNA gene PCR and in 74/76 (97.4\%) by real-time MgPa gene PCR. Real-time MgPa gene PCR thus had higher sensitivity compared with conventional 16S rRNA gene PCR and had considerably increased sensitivity compared with real-time $16 \mathrm{~S}$ rRNA gene PCR for detection of M. genitalium DNA. Real-time $\mathrm{MgPa}$ gene $\mathrm{PCR}$ is well suited for the clinical diagnosis of M. genitalium.
\end{abstract}

\section{INTRODUCTION}

Mycoplasma genitalium was first isolated in 1980 (Tully et al., 1981). There is strong evidence of M. genitalium having a causative role in non-chlamydia, non-gonococcal urethritis (NCNGU) in men and cervicitis in women (Deguchi \& Maeda, 2002; Jensen, 2004; Taylor-Robinson, 2002; Uusküla \& Kohl, 2002). M. genitalium infection has also been associated with pelvic inflammatory disease but

Abbreviations: FVU, first void urine; $\mathrm{MgPa}, M$. genitalium adhesin protein; NCNGU, non-chlamydia, non-gonococcal urethritis; NGU, non-gonococcal urethritis; STI, sexually transmitted infections. the exact role has not yet been determined (Cohen et al., 2002). In genital tract infection, the clinical implications of $M$. genitalium infection may not differ significantly from those of the well-established pathogens Chlamydia trachomatis and Neisseria gonorrhoeae (Falk et al., 2004, 2005). Repeated attempts have been made to recover this extremely fastidious organism from clinical samples by culture techniques but isolates have been rare and difficult to obtain. Serology for the diagnosis of $M$. genitalium infection has not been widely used because of crossreactivity with other mycoplasmas (Lind et al., 1984; Taylor-Robinson et al., 1983). With the development of PCR methods in the early 1990s, detection of M. genitalium 
infection became more feasible. In 1991, conventional PCR for $M$. genitalium targeting the $M$. genitalium adhesin protein $(\mathrm{MgPa})$ gene was introduced (Jensen et al., 1991). This method was subsequently used in $M$. genitalium studies (Gambini et al., 2000; Martinelli et al., 1999). Jensen et al. (2004b) presented a further development of the MgPa gene PCR for application in real-time PCR. Other methods are based on the 16S rRNA gene of $M$. genitalium and have also been used with both conventional and real-time PCR to detect $M$. genitalium infection (Björnelius et al., 2000; Jensen et al., 2003; Jurstrand et al., 2005; Yoshida et al., 2002). In a review by Jensen (2004), there was an urge for more studies of $M$. genitalium infection in women as fewer studies have been published on women compared with men. There is also a lack of studies addressing the prevalence in both men and women from the same catchment area. The aim of this study was to compare conventional 16S rRNA gene PCR, real-time 16S rRNA gene PCR and real-time $\mathrm{MgPa}$ gene PCR as detection methods for $M$. genitalium and to determine the prevalence of M. genitalium in patients, both male and female, attending a sexually transmitted infections (STI) clinic in a rural area in Sweden.

\section{METHODS}

Patients and clinical specimens. From April to October 2003, specimens were obtained from 381 men (18-82 years of age, median 27 years) and 298 women (17-55 years of age, median 25 years) attending the STI clinic at the Central Hospital Karlstad, Sweden. All new attendees who were at risk of being infected with an STI due to unprotected sex with a new partner or having a sexual partner who was PCR-positive for M. genitalium were enrolled in the study after providing informed consent. Fewer than ten patients declined to be enrolled. Following a standard protocol, the patients were asked for historical symptoms and on-going symptoms of urethritis/cervicitis (dysuria, urethral and cervical discharge, intermenstrual or post-coital bleeding and lower abdominal pain). A specimen for a smear was obtained with either a plastic loop or a small swab from the distal urethra of men. The smears were stained with methylene blue. Patients with $\geqslant 5$ polymorphonuclear leukocytes per high-power $(\times 1000)$ microscopic field were considered to have urethritis. Following clinical examination, all men were asked to collect first void urine (FVU) for detection of M. genitalium. In patients with a urine bladder incubation time of $\leqslant 1 \mathrm{~h}$, a urethral swab specimen was collected instead using a rayon-tipped wire shaft Copan $160 \mathrm{C}$ and placed in $1.5 \mathrm{ml} 2$-SP medium containing $0.2 \mathrm{M}$ sucrose in $0.02 \mathrm{M}$ phosphate buffer ( $\mathrm{pH} 7.0), 10 \%$ inactivated fetal calf serum, garamycin $\left(20 \mu \mathrm{g} \mathrm{ml}^{-1}\right)$, vancomycin $\left(100 \mu \mathrm{g} \mathrm{ml}^{-1}\right)$ and Fungizone $\left(5 \mu \mathrm{g} \mathrm{ml}^{-1}\right)$. From women, an endocervical sample was obtained with a plastic loop from the posterial and lateral vaginal fornices for wet smear examination in $0.9 \% \mathrm{NaCl}$. Patients with more polymorphonuclear leukocytes than epithelial cells by microscopy were considered to have cervicitis. After the wet smear was taken, an endocervical swab for detection of M. genitalium was collected using a rayon-tipped wire shaft Copan $160 \mathrm{C}$ and placed in $1.5 \mathrm{ml} \mathrm{2-SP}$ medium. Following clinical examination, all women were asked to collect FVU for detection of M. genitalium. FVU was gathered in a $10 \mathrm{ml}$ screwcapped polypropylene tube (Sarstedt). In patients with a urine bladder incubation time of $\leqslant 1 \mathrm{~h}$, a urethral swab specimen was collected instead of FVU using a rayon-tipped wire shaft Copan $160 \mathrm{C}$ and placed in $1.5 \mathrm{ml} \mathrm{2-SP} \mathrm{medium.}$
Diagnostic tests. In the PCR comparative study, we used 213 specimens: 98 consecutively sampled specimens from patients enrolled in the prevalence study, 36 consecutively sampled specimens from patients with symptoms of urethritis and 79 selected specimens from patients positive for $M$. genitalium in the prevalence study by real-time MgPa gene PCR.

\section{DNA extraction}

For real-time PCR. A volume of $1800 \mu \mathrm{l}$ from urine specimens was centrifuged at $20000 \mathrm{~g}$ for $15 \mathrm{~min}$. Aliquots of swab specimens $(100 \mu \mathrm{l})$ in 2-SP medium were mixed with $1 \mathrm{ml} 0.85 \% \mathrm{NaCl}$ prior to centrifugation as for the urine specimens. The pellet was resuspended in $300 \mu \mathrm{l} 5 \%(\mathrm{w} / \mathrm{v})$ Chelex 100 slurry (Bio-Rad) in distilled water, vortexed for $60 \mathrm{~s}$ and incubated at $99{ }^{\circ} \mathrm{C}$ for $10 \mathrm{~min}$. Finally, the specimens were centrifuged at $12000 \mathrm{~g}$ for $5 \mathrm{~min}$ and the supernatant was analysed by real-time $16 \mathrm{~S}$ rRNA gene PCR and real-time $\mathrm{MgPa}$ gene PCR.

For conventional PCR. DNA extraction for the conventional $16 \mathrm{~S}$ rRNA gene PCR was performed as described previously by Jensen et al. (2004a). Briefly, $100 \mu \mathrm{l}$ swab specimen in 2-SP medium was mixed with $300 \mu \mathrm{l} 20 \%$ (w/v) Chelex 100 slurry in TE buffer [10 mM Tris/ $\mathrm{HCl}(\mathrm{pH} 8.0), 1 \mathrm{mM}$ EDTA], vortexed for $60 \mathrm{~s}$ and incubated at $95{ }^{\circ} \mathrm{C}$ for $10 \mathrm{~min}$. After centrifugation at $20000 \mathrm{~g}$ for $5 \mathrm{~min}$, the supernatant was analysed by conventional $16 \mathrm{~S}$ rRNA gene PCR. Urine specimens were concentrated by centrifugation: $1800 \mu \mathrm{l}$ was centrifuged at $20000 \mathrm{~g}$ for $15 \mathrm{~min}$. Chelex 100 slurry $(300 \mu \mathrm{l})$ was added to the pellet and the mixture was treated as described above for the swab specimens.

Real-time MgPa gene PCR. The PCR was carried out in a $25 \mu \mathrm{l}$ SmartCycler reaction tube containing $1 \times$ reaction buffer, $3.5 \mathrm{mM}$ $\mathrm{MgCl}_{2}, 200 \mu \mathrm{M}$ dNTP mix, $0.625 \mathrm{U}$ Hot Gold Star Taq polymerase (Eurogentec), $1.0 \mu \mathrm{M}$ each primer using the previously described (Jensen et al., 2004b) forward primer $\mathrm{MgPa}-355 \mathrm{~F}$ and reverse primer $\mathrm{MgPa}-432 \mathrm{R}$ (Cybergene) and $0.1 \mu \mathrm{M} \mathrm{MgPa}-380$ Taqman MGB probe (Applied BioSystems) (Table 1). Subsequently, $5 \mu$ template DNA was added to the mixture. Amplification was performed in a SmartCycler (Cepheid) under the following conditions: Hot Gold Star Taq polymerase activation at $95{ }^{\circ} \mathrm{C}$ for $10 \mathrm{~min}$, followed by a touch-down protocol of 1 cycle of denaturation at $95{ }^{\circ} \mathrm{C}$ for $15 \mathrm{~s}$, annealing at $64{ }^{\circ} \mathrm{C}$ for $30 \mathrm{~s}$ and extension at $72{ }^{\circ} \mathrm{C}$ for $30 \mathrm{~s} ; 1$ cycle of denaturation at $95{ }^{\circ} \mathrm{C}$ for $15 \mathrm{~s}$, annealing at $62{ }^{\circ} \mathrm{C}$ for $30 \mathrm{~s}$ and extension at $72{ }^{\circ} \mathrm{C}$ for $30 \mathrm{~s}$; and 48 cycles of denaturation at $95{ }^{\circ} \mathrm{C}$ for $15 \mathrm{~s}$, annealing at $60{ }^{\circ} \mathrm{C}$ for $30 \mathrm{~s}$ and extension at $72{ }^{\circ} \mathrm{C}$ for $30 \mathrm{~s}$.

Real-time 16S rRNA gene PCR. The PCR was carried out in a $20 \mu \mathrm{l}$ LightCycler glass capillary. Primers and probes in this PCR assay were designed previously as a further development of the conventional PCR (Jensen et al., 2003). The $18 \mu \mathrm{l}$ reaction mix contained FastStart DNA Master Hybridization Probe mix, containing FastStart Taq polymerase, reaction buffer, dNTP mix, $10 \mathrm{mM} \mathrm{MgCl}_{2}$ (Roche Diagnostics), $0.6 \mu \mathrm{M}$ forward primer MG16-45F and $0.4 \mu \mathrm{M}$ reverse primer MG16-447R (Scandinavian Gene Synthesis). Two hybridization probes, Mg16S-137 and Mg16S-169 (TIB-Molbiol), were used at a final concentration of $0.2 \mu \mathrm{M}$ each (Table 1). Additional $\mathrm{MgCl}_{2}$ was added to a final concentration of $5 \mathrm{mM}$. An aliquot $(2 \mu \mathrm{l})$ of template DNA was added to the mixture. Amplification was performed on a LightCycler PCR system (Roche Molecular Biochemicals) under the following conditions: FastStart Taq polymerase activation at $95{ }^{\circ} \mathrm{C}$ for $10 \mathrm{~min}$, followed by 50 cycles of denaturation at $95{ }^{\circ} \mathrm{C}$ for $10 \mathrm{~s}$, annealing at $60{ }^{\circ} \mathrm{C}$ for $10 \mathrm{~s}$ and extension at $72{ }^{\circ} \mathrm{C}$ for $16 \mathrm{~s}$ (Jurstrand et al., 2005).

Conventional 16S rRNA gene PCR. The conventional 16S rRNA gene PCR was performed as described previously by Jensen et al. (2003). In brief, the PCR was carried out with a final reaction volume 
Table 1. Primers and probes used for M. genitalium PCR assays

\begin{tabular}{|c|c|c|c|}
\hline Primer/probe & $\begin{array}{c}\text { Primer/probe } \\
\text { name }\end{array}$ & Sequence $5^{\prime} \rightarrow 3^{\prime}$ & $\begin{array}{l}\text { Nucleotide } \\
\text { position }\end{array}$ \\
\hline \multirow[t]{2}{*}{ Primers for SmartCycler assay } & $\mathrm{MgPa}-355 \mathrm{~F}$ & GAGAAATACCTTGATGGTCAGCAA & $1420-1443^{*}$ \\
\hline & $\mathrm{MgPa}-432 \mathrm{R}$ & GTTAATATCATATAAAGCTCTACCGTTGTTATC & $1497-1465^{*}$ \\
\hline \multirow{2}{*}{$\begin{array}{l}\text { Primers for conventional and } \\
\text { LightCycler assay }\end{array}$} & MG16-45F & TACATGCAAGTCGATCGGAAGTAGC & $45-69 \dagger$ \\
\hline & MG16-447R & AAACTCCAGCCATTGCCTGCTAG & $469-447 \dagger$ \\
\hline Probe for SmartCycler assay & $\mathrm{MgPa}-380$ & FAM-ACTTTGCAATCAGAAGGT-MGB & $1445-1462^{*}$ \\
\hline \multirow[t]{2}{*}{ Probes for LightCycler assay } & Mg16S-137 & LC-red 640-AATTCATGCGAACTAAAGTTCTTATGCGGTATTAGCT-phosphate & $181-145 \dagger$ \\
\hline & Mg16S-169 & AATAACGAACCCTTGCAGGTCCTTTCAACTT-fluorescein & $213-183 \dagger$ \\
\hline
\end{tabular}

${ }^{\star} \mathrm{MgPa}$ operon sequence (GenBank accession no. M31431).

$\dagger 16 \mathrm{~S}$ rRNA gene sequence (GenBank accession no. X77334).

of $100 \mu \mathrm{l}$ containing $1 \times$ PCR buffer (Super Taq buffer; HT Biotechnology) with $2.5 \mathrm{mM} \mathrm{MgCl} 2 ; 0.4 \mathrm{mM}$ each primer (Table 1); $62.5 \mu \mathrm{M}$ each dATP, dGTP and dCTP; $125 \mu \mathrm{M}$ dUTP; $10 \mu \mathrm{l}$ of the appropriate dilution of internal process control; and $2 \mathrm{U}$ Taq polymerase (Platinum Taq; Life Technologies). A Perkin Elmer 9600 thermal cycler was used with $0.2 \mathrm{ml}$ MicroAmp tubes. After denaturation at $94{ }^{\circ} \mathrm{C}$ for $2 \mathrm{~min}, 40$ cycles were performed. The first ten cycles were used in a touch-down procedure and consisted of denaturation at $94{ }^{\circ} \mathrm{C}$ for $15 \mathrm{~s}$, annealing at $72-62{ }^{\circ} \mathrm{C}$ for $30 \mathrm{~s}$ with a $1{ }^{\circ} \mathrm{C}$ decrement per cycle and extension at $72{ }^{\circ} \mathrm{C}$ for $15 \mathrm{~s}$. The following 30 cycles consisted of denaturation at $92{ }^{\circ} \mathrm{C}$ for $15 \mathrm{~s}$, annealing at $62{ }^{\circ} \mathrm{C}$ for $30 \mathrm{~s}$ and extension at $72{ }^{\circ} \mathrm{C}$ for $30 \mathrm{~s}$. Amplicons were visualized after electrophoresis on $2 \%$ agarose gels containing $1 \mu \mathrm{g}$ ethidium bromide $\mathrm{ml}^{-1}$ and examined by UV transillumination.

DNA sequencing. The PCR products were purified by a standard ethanol precipitation method. In brief, $50 \mu$ PCR product was mixed with $5 \mu \mathrm{l} 3 \mathrm{M}$ sodium acetate ( $\mathrm{pH} 4.6)$ and $100 \mu \mathrm{l} 95 \%$ ethanol in a $1.5 \mathrm{ml}$ microcentrifuge tube. The tubes were left at $-20{ }^{\circ} \mathrm{C}$ for 30-40 min to precipitate the PCR products. Following the freeze precipitation, the tubes were centrifuged at $20000 \mathrm{~g}$ for $20 \mathrm{~min}$. The supernatant was carefully aspirated and the pellets were rinsed with $300 \mu \mathrm{l} 70 \%$ ethanol. The tubes were then centrifuged at $20000 \mathrm{~g}$ for $5 \mathrm{~min}$. Again, the supernatant was carefully aspirated and discarded. The pellets were left to dry at room temperature and then resuspended in $50 \mu \mathrm{l}$ sterile water. The purified PCR products were then DNA sequenced using an ABI BigDye Terminator Cycle Sequencing Ready Reaction kit (Applied Biosystems) using the same primers used for the MgPa gene real-time PCR assay. Sequencing reactions were purified using a DyeEx 2.0 Spin kit (Qiagen) before separation using an ABI PRISM 310 Genetic Analyzer (Applied Biosystems). The nucleotide sequences were analysed using CromaPro version 1.33 software and compared with sequence databases at the National Center for Biotechnology Information, using the basic local alignment search tool (BLAST) at http:// www.ncbi.nlm.nih.gov/BLAST/.

\section{RESULTS}

\section{Prevalence}

Patients. M. genitalium was detected in $27 / 381$ men $(7.1 \%)$ and in $23 / 298$ women $(7.7 \%)$ by real-time $\mathrm{MgPa}$ gene PCR.
Specimens from men. M. genitalium was found in 27/361 $(7.5 \%)$ single urine specimens tested. Five men provided a urethral swab specimen together with a urine specimen, whereas 15 men submitted only a urethral swab specimen. None of these specimens was positive for M. genitalium. Clinical information from the $27 \mathrm{M}$. genitalium PCR-positive men showed a $59 \%$ concordance between a positive PCR result and symptoms of urethritis and/or a positive urethral smear indicating urethritis.

Specimens from women. A cervical swab specimen together with a urine specimen was provided by 255 women and $19(7.5 \%)$ were positive for M. genitalium in either specimen (ten urine- and endocervical-positive; eight urine-positive and endocervical-negative; one urinenegative and endocervical-positive). A FVU specimen only was submitted from four women, none of which was positive for M. genitalium. A cervical swab specimen only was obtained from 30 women from whom M. genitalium was found in two $(6.7 \%)$. Nine women provided a urethral swab specimen together with a cervical swab specimen. Of these, two were positive in either specimen (one cervicalpositive and urethral-negative; one cervical-negative and urethral-positive) for M. genitalium (Table 2). Clinical information from the $23 \mathrm{M}$. genitalium PCR-positive women showed a $30 \%$ concordance between a positive PCR result and symptoms of cervicitis and/or a positive wet smear indicating cervicitis.

\section{PCR comparative study}

A total of 213 specimens were used in the PCR comparative study. The real-time MgPa gene PCR assay established a 92 and $89.7 \%$ agreement in comparison with analysis results obtained with the conventional 16S rRNA gene PCR and real-time 16S rRNA gene PCR assays, respectively. A $93 \%$ agreement was demonstrated in analysis results in comparison between real-time 16S rRNA gene PCR and conventional $16 \mathrm{~S}$ rRNA gene PCR assays. Seventy-six 
Table 2. Distribution according to specimen type of $23 \mathrm{M}$. genitalium PCR-positive specimen sets from 298 women included in the prevalence study

ND, Not determined.

\begin{tabular}{|lccc|}
\hline $\begin{array}{l}\text { Cervical } \\
\text { swab }\end{array}$ & $\begin{array}{c}\text { Urethral } \\
\text { swab }\end{array}$ & $\begin{array}{c}\text { First void } \\
\text { urine }\end{array}$ & \begin{tabular}{c} 
M. genitalium-positive \\
\hline+
\end{tabular} \\
+ & ND & 0 \\
+ & - & ND & 1 \\
- & + & ND & 1 \\
- & ND & + & 8 \\
+ & ND & + & 10 \\
+ & ND & - & 1 \\
+ & ND & ND & 2 \\
\hline
\end{tabular}

specimens were considered to be true-positive specimens defined as either a specimen positive in any two PCR assays or a specimen whose PCR product was verified by DNA sequencing. Forty-nine specimens were positive in all three assays (Fig. 1). Ten specimens were positive only by conventional $16 \mathrm{~S}$ rRNA gene PCR and real-time $\mathrm{MgPa}$ gene PCR. Three specimens were positive only by real-time $16 \mathrm{~S}$ rRNA gene $\mathrm{PCR}$ and real-time $\mathrm{MgPa}$ gene PCR. Twelve specimens were positive for $M$. genitalium only by real-time $\mathrm{MgPa}$ gene PCR. Four of these specimens came from women with another truepositive sample. All 12 specimens were retested with the real-time $\mathrm{MgPa}$ gene PCR and the PCR products were verified by DNA sequencing (data not shown). Two specimens were positive for $M$. genitalium only by conventional 16S rRNA gene PCR. These two specimens also came from women with another true-positive sample. Both specimens were able to be retested by real-time $\mathrm{MgPa}$ gene PCR and the PCR products were verified by DNA sequencing.

\section{DISCUSSION}

The main purpose of this study was to compare different PCR assays for the detection of M. genitalium in urogenital specimens from men and women. We also wanted to determine the prevalence of M. genitalium in patients, both male and female, attending an STI clinic in the study catchment area. Many clinical studies published to date have used primers targeting the $M$. genitalium adhesin gene according to Jensen (2006). Moreover, the majority of studies to date on $M$. genitalium have used conventional PCR as the detection method. Yoshida et al. (2002) published the first real-time PCR assay for detection of $M$. genitalium. In the current study, 213 specimens were used to compare two different real-time PCR assays targeting the $\mathrm{MgPa}$ gene and the $16 \mathrm{~S}$ rRNA gene of M. genitalium. We also compared results with conventional 16S rRNA gene PCR. The real-time MgPa gene PCR assay, using the $\mathrm{MgPa}-355 \mathrm{~F} / 432 \mathrm{R}$ primers published by Jensen et al. (2004b), detected 12 specimens in the PCR comparative study that were not able to be detected by the two other assays tested. These specimens were retested and the PCR products were verified by DNA sequencing as containing M. genitalium DNA. Four of the retested specimens came from women with another true-positive sample, which verified the result. However, the possibility of contamination rendering the remaining eight specimens positive could not be excluded. Two specimens were found to be positive for M. genitalium only by conventional $16 \mathrm{~S}$ rRNA gene PCR. These two specimens also came from women with another true-positive sample. Both specimens were able to be retested with real-time MgPa gene PCR and the PCR products were verified by DNA sequencing. No retested specimens could be subjected to a new DNA extraction due to insufficient specimen material left after three previous DNA extractions. Previous studies have also demonstrated lower sensitivity for real-time 16S rRNA gene PCR compared with conventional 16S rRNA gene PCR. Jurstrand et al. (2005) showed $72.2 \%$ sensitivity and

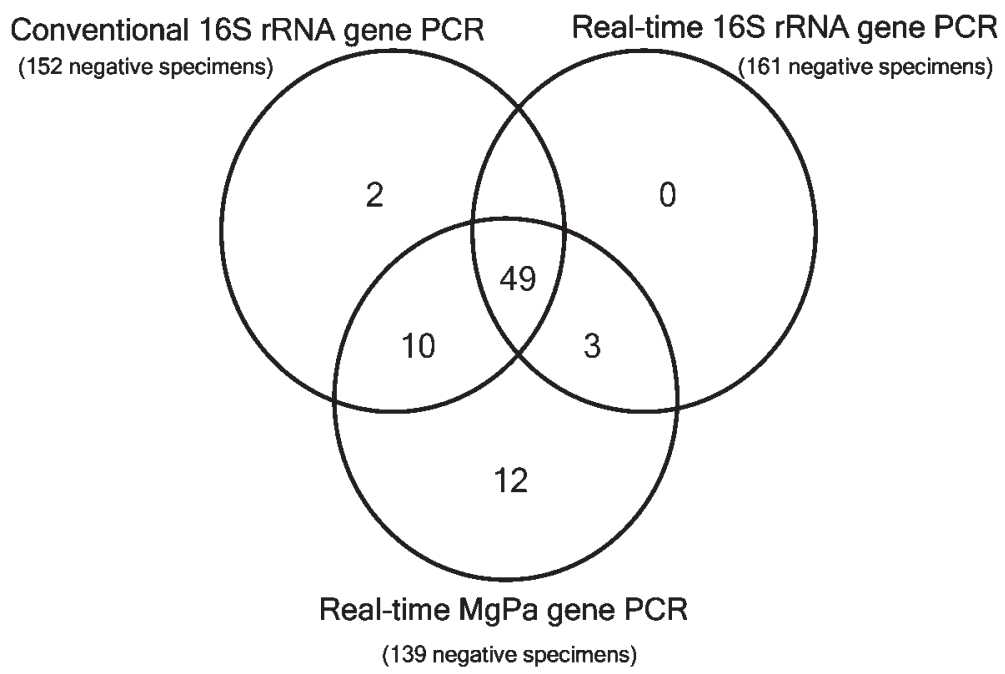

Fig. 1. Distribution of 213 specimens (76 positive and 137 negative) in a comparison of real-time $16 \mathrm{~S}$ rRNA gene PCR, conventional 16S rRNA gene PCR and real-time $\mathrm{MgPa}$ gene PCR assays for detection of $M$. genitalium. Positive specimens are indicated within the circles. 
99.7\% specificity for real-time PCR compared with conventional PCR for detection of $M$. genitalium in urogenital specimens from men. Recently, Svenstrup et al. (2005) evaluated real-time MgPa gene PCR, real-time gap gene PCR and conventional 16S rRNA gene PCR as detection methods for M. genitalium in 246 urethral swab specimens from men. Real-time MgPa gene PCR proved to be the most sensitive method, detecting $M$. genitalium DNA in three specimens that were negative by real-time gap gene PCR (range $0.03-2.65$ copies $\mu \mathrm{l}^{-1}$ ). A low load of M. genitalium DNA in clinical specimens underlines the need for highly sensitive assays. Jensen et al. (2004a) demonstrated that $28 \%$ of urethral swab specimens and $14 \%$ of FVU specimens contained less than ten genome equivalents of $M$. genitalium DNA. In our PCR comparative study, the real-time $16 \mathrm{~S}$ rRNA gene PCR was performed on a LightCycler using only $2 \mu$ template DNA, whilst the real-time MgPa gene PCR was performed on a SmartCycler using $5 \mu \mathrm{l}$ template DNA. This could explain the lower sensitivity for the real-time 16S rRNA gene assay. However, the conventional $16 \mathrm{~S}$ rRNA gene PCR had the advantage of being performed with a total volume of $100 \mu$ l, allowing $10 \mu \mathrm{l}$ template DNA to be analysed. The conventional assay increased the sensitivity of the $16 \mathrm{~S}$ rRNA gene assay somewhat, but clearly using the adhesin gene as the target provided a more sensitive PCR method for detection of M. genitalium. All clinical specimens in this study were subjected to a crude Chelex extraction of DNA as the sample preparation method. In a recent study at the Department of Clinical Microbiology, Central Hospital, Karlstad, Sweden, we demonstrated a $6 \%$ partial inhibition compared with $<1 \%$ partial inhibition in specimens prepared by Chelex extraction compared with an automated extraction using a MagAttract DNA Mini M48 kit (Qiagen) on a GenoM48 Biorobot (F. Aronsson, personal communication). In our PCR comparative study, only the conventional 16S rRNA gene PCR assay used an internal control for inhibition in the set-up. Inhibitors and the probability of low DNA load in specimens emphasize the need for improved protocols for specimen preparation to increase the sensitivity in assays for clinical purpose. There is an urge for more studies of M. genitalium infection in women as claimed by Jensen (2004), as more studies have been published on men. There are only a few studies addressing the prevalence in both men and women from the same catchment area. A study of M. genitalium in nongonococcal urethritis (NGU) in Swedish male STI patients showed a high occurrence of 26 and $36 \%$ in patients with NGU and with NCNGU, respectively, compared with $10 \%$ in control patients without urethritis (Björnelius et al., 2000). A prevalence study on M. genitalium in relation to the number of life-time sexual partners in patients visiting STI clinics in western Sweden showed considerably lower numbers of infected patients. Seven per cent of the examined men, $14 \%$ of men with urethritis, $3.5 \%$ of the examined women and $1 \%$ of the control patients without urethritis were infected with M. genitalium (Johannisson et al., 2000). Other Swedish studies have shown a prevalence in concordance with our results (Anagrius et al., 2005; Falk et al., 2004, 2005). Mellenius et al. (2005) presented slightly lower numbers of prevalence compared with our study: $4.1 \%$ in men and $3.8 \%$ in women. The clinical information from men and women in our study showed a $59 \%$ concordance for men and a $30 \%$ concordance for women between a positive PCR result for $M$. genitalium and symptoms of urethritis/cervicitis and/or a positive ureth$\mathrm{ral} /$ wet smear indicating urethritis/cervicitis. This is a lower proportion than previous reports for men but is congruent with other reports for women (Falk et al., 2004, 2005). The lower percentage for men could be attributed to the fact that a plastic loop or a swab was used instead of a blunt curette in sampling. Several recent studies on M. genitalium have utilized real-time PCR as the detection method. The realtime MgPa gene PCR can be used in a quantitative setting, determining the M. genitalium load in clinical specimens, which may prove to be useful in clinical studies, giving information about the number of organisms. To our knowledge, this is the first comparison between two realtime PCR methods for detection of $M$. genitalium using specimens from both men and women. In conclusion, realtime $\mathrm{MgPa}$ gene PCR demonstrated higher sensitivity compared with conventional 16S rRNA gene PCR and considerably increased sensitivity compared with real-time 16S rRNA gene PCR for detection of M. genitalium DNA. It has a number of advantages over conventional PCR as it is a closed format, decreasing the contamination risk, it is less labour-intensive and the use of probes increases specificity. With the implementation of an internal processing control, this method will be well suited for clinical diagnostics of $M$. genitalium in urogenital specimens from men and women.

\section{ACKNOWLEDGEMENTS}

We are grateful for the excellent work of the staff at the outpatient STI clinic, Karlstad Central Hospital, during the study. We are also grateful for excellent technical assistance with the DNA sequencing by Paula Mölling, Department of Clinical Microbiology, Örebro University Hospital. This work was partly supported by grants from the Örebro University Hospital Foundation and Värmland County Hospital Foundation.

\section{REFERENCES}

Anagrius, C., Lore, B. \& Jensen, J. S. (2005). Mycoplasma genitalium: prevalence, clinical significance, and transmission. Sex Transm Infect 81, 458-462.

Björnelius, E., Lidbrink, P. \& Jensen, J. S. (2000). Mycoplasma genitalium in non-gonococcal urethritis - a study in Swedish male STD patients. Int J STD AIDS 11, 292-296.

Cohen, C. R., Manhart, L. E., Bukusi, E. A., Astete, S., Brunham, R. C., Holmes, K. K., Sinei, S. K., Bwayo, J. J. \& Totten, P. A. (2002). Association between Mycoplasma genitalium and acute endometritis. Lancet 359, 765-766.

Deguchi, T. \& Maeda, S. (2002). Mycoplasma genitalium: another important pathogen of nongonococcal urethritis. J Urol 167, 1210-1217. 
Falk, L., Fredlund, H. \& Jensen, J. S. (2004). Symptomatic urethritis is more prevalent in men infected with Mycoplasma genitalium than with Chlamydia trachomatis. Sex Transm Infect 80, 289-293.

Falk, L., Fredlund, H. \& Jensen, J. S. (2005). Signs and symptoms of urethritis and cervicitis among women with or without Mycoplasma genitalium or Chlamydia trachomatis infection. Sex Transm Infect 81, 73-78.

Gambini, D., Decleva, I., Lupica, L., Ghislanzoni, M., Cusini, M. \& Alessi, E. (2000). Mycoplasma genitalium in males with nongonococcal urethritis: prevalence and clinical efficacy of eradication. Sex Transm Dis 27, 226-229.

Jensen, J. S. (2004). Mycoplasma genitalium: the aetiological agent of urethritis and other sexually transmitted diseases. J Eur Acad Dermatol Venereol 18, 1-11.

Jensen, J. S. (2006). Mycoplasma genitalium infections. Diagnosis, clinical aspects, and pathogenesis. Dan Med Bull 53, 1-27.

Jensen, J. S., Uldum, S. A., Søndergård-Andersen, J., Vuust, J. \& Lind, K. (1991). Polymerase chain reaction for detection of Mycoplasma genitalium in clinical samples. J Clin Microbiol 29, 46-50.

Jensen, J. S., Borre, M. B. \& Dohn, B. (2003). Detection of Mycoplasma genitalium by PCR amplification of the 16S rRNA gene. J Clin Microbiol 41, 261-266.

Jensen, J. S., Björnelius, E., Dohn, B. \& Lidbrink, P. (2004a). Comparison of first void urine and urogenital swab specimens for detection of Mycoplasma genitalium and Chlamydia trachomatis by polymerase chain reaction in patients attending a sexually transmitted disease clinic. Sex Transm Dis 31, 499-507.

Jensen, J. S., Björnelius, E., Dohn, B. \& Lidbrink, P. (2004b). Use of TaqMan $5^{\prime}$ nuclease real-time PCR for quantitative detection of Mycoplasma genitalium DNA in males with and without urethritis who were attendees at a sexually transmitted disease clinic. J Clin Microbiol 42, 683-692.

Johannisson, G., Enström, Y., Löwhagen, G. B., Nagy, V., Ryberg, K., Seeberg, S. \& Welinder-Olsson, C. (2000). Occurrence and treatment of Mycoplasma genitalium in patients visiting STD clinics in Sweden. Int J STD AIDS 11, 324-326.
Jurstrand, M., Jensen, J. S., Fredlund, H., Falk, L. \& Mölling, P. (2005). Detection of Mycoplasma genitalium in urogenital specimens by realtime PCR and by conventional PCR assay. J Med Microbiol 54, 23-29.

Lind, K., Lindhardt, B. Ø., Schütten, H. J., Blom, J. \& Christiansen, C. (1984). Serological cross-reactions between Mycoplasma genitalium and Mycoplasma pneumoniae. J Clin Microbiol 20, 1036-1043.

Martinelli, F., Garrafa, E., Turano, A. \& Caruso, A. (1999). Increased frequency of detection of Ureaplasma urealyticum and Mycoplasma genitalium in AIDS patients without urethral symptoms. J Clin Microbiol 37, 2042-2044.

Mellenius, H., Boman, J., Lundqvist, E. N. \& Jensen, J. S. (2005). Mycoplasma genitalium should be suspected in unspecific urethritis and cervicitis. A study from Vasterbotten confirms the high prevalence of the bacteria. Lakartidningen 102, 3538, 3540-3541.

Svenstrup, H. F., Jensen, J. S., Björnelius, E., Lidbrink, P., Birkelund, S. \& Christiansen, G. (2005). Development of a quantitative real-time PCR assay for detection of Mycoplasma genitalium. J Clin Microbiol 43, 3121-3128.

Taylor-Robinson, D. (2002). Mycoplasma genitalium - an up-date. Int J STD AIDS 13, 145-151.

Taylor-Robinson, D., Furr, P. M. \& Tully, J. G. (1983). Serological cross-reactions between Mycoplasma genitalium and M. pneumoniae. Lancet 1, 527.

Tully, J. G., Taylor-Robinson, D., Cole, R. M. \& Rose, D. L. (1981). A newly discovered mycoplasma in the human urogenital tract. Lancet 1, 1288-1291.

Uusküla, A. \& Kohl, P. K. (2002). Genital mycoplasmas, including Mycoplasma genitalium, as sexually transmitted agents. Int J STD AIDS 13, 79-85.

Yoshida, T., Deguchi, T., Ito, M., Maeda, S., Tamaki, M. \& Ishiko, H. (2002). Quantitative detection of Mycoplasma genitalium from firstpass urine of men with urethritis and asymptomatic men by real-time PCR. J Clin Microbiol 40, 1451-1455. 